\title{
Content Analysis of Promotional Messages Conveyed by Retailers in Mannar District
}

\author{
MARY THIRESA.S \\ Ex-student, Department of Marketing, University of Jaffna \\ Email: jolythiresa@gmail.com \\ SHIVANY.S \\ Senior Lecturer, Department of Marketing, University of Jaffna \\ Email: shanshivany@yahoo.com
}

\begin{abstract}
Since the beginning of conflict resolution in Sri Lanka, Retailers in Mannar have been promoting their products to consumers via different media vehicles. Over the years, the promotional processes and systems used by retailing have been tailored and modified in order to meet the demands of the consumers. Nowadays promotional messages are greatest important to all business to realize the objectives of the businesses successfully. Suitable promotional messages support consumers for their purchase decisions. Promotional message content is important, because those fascinate consumers. Today's retailers must find new ways to attract consumers and inspire high levels of customer retention. Purpose of this research is to identify the different contents of promotional messages conveyed by the retailers in Mannar, where many retailers penetrated after conflict resolution. This research analyzed the contents of promotional messages in 24 Newspaper Advertisements and 26 Catalogs. This research frequently identified the contents of pesticides and herbicides promotional messages. Based on Carlson's classification contents are summarized based on product oriented, process oriented, Image oriented, environmental reality orientated and integrated promotional messages. Content analysis was used to classify those promotional messages into five categories. Different promotional messages are identified from the different product advertisements. There is inadequate promotional messages on environmental reality, and integrated messages identified in this study. Consumers seek for innovation, creativity as well as the environmental friendly concern. Therefore, present study provides implications to retail sector in Mannar to design further promotional messages which integrate the orientations on product, process, Image, and Environmental reality.
\end{abstract}

Keywords: Advertisements, Content Analysis, Catalogues, Promotional Messages, Retailers.

\section{Introduction}

Retailers role in retail marketing is to promote and guide the customers to purchase products in planned or unplanned behavior, and they should encourage them to have a greatest experience, as well as enjoyable memories at the retail market (Levi \& Weitz, 2009). Promotional message includes all the vehicles used in getting the attention of customer to make them aware of a brand, a product, or a company. Its main purposes are generating sales and developing customer retention. Retail Promotional messages are designed to inform, persuade, or remind. Promotional messages are closely related with four Ps of the marketing mix: product, place, price and promotion. It is also one of the seven functions of marketing, the other six being pricing, product and service management, place, people, process and physical environment. Objectives of promotional messages are to give information, to increase demand for a particular brand or 
product, to differentiate the brand or the company from its competitors, to highlight the value or benefits of the product, to increase and stabilize sales. When organizations are making decisions about promotional messaging the objectives need to be stated clearly and should be measurable. Promotional messages must support the overall goals of the organization and focus on its strategies for successfully competing in the given market. In todays the promotional messages are most important to retailers and customers. Retailers convey the details about their product to the customers through the promotional messages in Catalogs and newspapers. consumers can obtain more awareness of particular product of retailers. The consumers are mostly attracted by promotional messages.

Promotional messages mean used in bringing customers from a state of relative unawareness to a state of actively adopting the product (Cole ,2011). Its means of communicating with individuals, groups, or organizations to directly or indirectly facilitate exchange of information and persuading one or more audience to accept an organization's product. Promotion as the total marketing communication program of a particular product (Ross et al ,2011). Retail companies have always been close to consumers are now also economically powerful. Strong retail enterprises, organized as chains, decide nowadays what will be offered to the consumers. Their market supply is not limited to producers' brands, but, more and more often, they take the lead on sales by increasing the share of their own brand products. As far as their own brand products are concerned, major retailers, while competing on price, promotion are also positioning their offers on attributes other than price.

A study of Speck \& Elliot (1997) analyzed that the Advertising message is a potent and extremely prevalent form of communication in America. Influencing consumers through advertising also require believability. In a survey believability was rated as high importance in an advertisement message (Speck \& Elliot, 1997). Not only must an advertisement influence the consumer, it must be presented in a way, so the consumer believes its message.

Joergens (2006) explained the impact of advertising message strategy. This study focuses upon the advertising message strategies used by American Apparel, a global apparel retailer recognized for its socially responsible production practices, and in particular, for its commitment to fair labour (Joergens, 2006). Researchers have devised models to demonstrate the hierarchical effects of advertising on purchase intention (Mitchell and Olson ,1981).

Retailers offer the desired choice by delivering a wide range of retail formats and goods (Clarke et al., 2004), but they also shape, construct and bound consumer choice: physically, by the choice of products; materially, by the price of these products; and symbolically, by creating meaning and identity for the consumer. In today's competitive marketplace retailers should ensure that messages reach consumers about products and services are clear, and concise.

Marketing problems can be solved through the promotional strategies. Promotional message is a way expressing the message contents' products, what they have to attract the consumers. Many past studies identified that green promotion messages can be used as a strategy to survive in the market (Zuhairah Hasan, Noor Azman A, 2015). Retailers compete with them to attract the customers in a geographical segment. Identifying the content of the promotional messages helps the retailers to figure those advertisements on the preferences of customers accordingly. After conflict resolution what are promotional messages target to customers will be enrich the current knowledge in the classification of promotional messages. This research fills the gap by researching promotional messages conveyed by the retailers in manner district.

\section{Research Objectives}

1. To identify the contents of promotional messages conveyed by the retailers in Mannar.

2. To categories the promotional messages on Based on Carlson's classification. 


\section{Related Literature Review}

The promotional message going back in time and taking its name frame the items when war time aircraft dropped them on to enemy cities for propaganda is a printed means of weekly or monthly communication for retailers and distributers both in store and out of store and employed to communicate deals with retailer image (Pieters et al.,2007). The promotional message commands a substantial part of retailer image. (Pargel et al.,2009; De camillas,2012; Gazquez Abad et, al,2009). Promotional message is often defined as marketing communication activities which do not include advertising selling or public relations or even more simply as special offers such definitions are very simplistic and do little to communicate the versatility variety and complexity of sale promotion in practices (Peattie and peattie,1994). Promotional messages are a crucial retail promotion tools because they influence shoppers both at home and in store and are source of marketing contributions from manufactures who are rely heavily on them to reach consumer directly. (Srinivasan et al, 1995; Yolle, 1997; Arnold et al., 2001; Minouni-Chaabane et al., 2010).

Ross (2001) sees promotional mix as "the total marketing communication programme of a particular product". Adebisi (2006) defined promotional mix as "any marketing effort whose function is to inform or persuades actual or potential consumers about the merit a product possesses for the purpose of inducing a consumer to either start buying or continue to purchases the firm's product."

Advertising is "one of the most prolific and all-encompassing forms of communication in the world" (Reichert, 2003). This form of company to customer communication raises concerns about the ethics of advertising because the practice of it is very persuasive and influential (Treise \& Weigold, 1994). Advertising has become a prominent means for organizations to create or adapt their image. Image creation is a public relations strategy that has increasingly targeted young adults and teens because they are not receptive to traditional direct advertising (Goodman \& Dretzin, 1999).

This is the process by which the seller sells to the consumer face to face. The personal selling consists of a selling process, which is illustrated below. Personal selling is the most expensive form of promotion. Company that use more of personal selling are said to be adopting push strategy while that of advertising are using pull strategy. Publicity differs from other promotional mix in that it is costless most of the time. Publicity according to Cole (1996) is "news about the organization or its products reported in the press". Publicity sometimes cost but its cost is always related with advertisement.

Public relation is another form of promotion. It is the means by which the organization related or communicates with the environment. Public relation is aimed at better customer relations and immediate feedback.The marketing and apparel literature generally agrees on the subject of fashion leadership in that fashion leaders are more likely to be young consumers (Goldsmith et al., 1991; Gutman and Mills, 1982; Horridge and Richards, 1984; Mason and Bellenger, 1974; Scrugge, 1977). When compared with other consumer groups, young fashion leaders are those consumers that consider fashion to be of great importance to their lifestyles.

The argument for choice editing is that in a sustainable society, environmentally sound choices should not be difficult to make, rather the sustainable choice should be the default choice (Maniates, 2010). Consumers benefit from choice editing as they are assured that critical sustainability issues are being dealt with upstream (Sustainable Consumption Roundtable,2006a) and consumers accept that sustainable choices are being edited for them (Goworek et al., 2012).

Consumer trust is predicated by public acceptance and consumer awareness of the issue at stake, and generally requires adequate knowledge in society of environmental issues and to some extent a consensus on accepting reduced sovereignty for the purposes of a "greater good" (Michaelis, 2002). Cristina Ziliani, Marco Ieva, (2015) in their research evaluated the recent evolution retail flyers to illustrate how a tool of traditional marketing can be applied to generate insight on customer "couch-to-cart" 
behaviour thus supporting an innovating shopper marketing approach. The authors support this position by elaborating on three themes: first, the recent evolution of flyers, driven by incorporation of customer insight derived from loyalty data and by new features enabled by flyer digitalization; second, the evolution of the flyer planning and management process, related to opportunities and challenges in the retailer organizational structure; and third, the rise of online flyer aggregators. Achchuthan \& Charles (2017) demonstrated that information on retailers contributes to enhancing a customer's favorable evaluation of the supermarket's physical aspects, personal interaction and retailing policy.

Michael Clayton, Jun Heo, (2011), suggested that that promotional-based messaging is detrimental to all three brand associations, with quality ratings witnessing the most significant declines. In addition, the current study observed no significant effects of involvement, as measured by attention to the message, on brand association measures for value-based messaging when compared with brand messaging.

Ian Phau, Denise Ong, (2007) enlightened that, Shoppers responded more positively to productrelated messages than cause-related messages. They found environmental claims to be more credible if attributed to the green brands than to the neutral brand. Though consumers are becoming increasingly green-minded, the result is not necessarily more consumption of green products, but "better" consumption behavior in general. Retailers should build a store image that clearly transmits their green credentials, as a proxy for the quality and nature of merchandise they carry.

\section{Methodology}

Research methodology is the one that provides guidelines to do a research systematically. Leedy and Ormroad (2001) defined research methodology as the general approach the researchers takes in carrying out the research project. Qualitative research helps researchers address issues in a specific context in their research disciplines. There are a number of research approaches which are included under the umbrella of qualitative methods. The social science disciplines have different conventions on best practices in qualitative research.

In this research the population is promotional messages conveyed by retailers in Manner. Sample is a subset of a population selected to participate in a study, it is a fraction of the whole, selected to participate in the research project (Brink 1996; Polit \& Hungler 1999) a general rule of the thumb is to always use the largest sample possible. The sample size of this study is 50 promotional messages, conveyed by the retailers in Mannar District. Promotional messages collected were advertised in 2016 during Januarymarch.

\section{Data Analysis}

Content analysis is an acceptable method for redeveloping tools and theories (Carlson et al. 1993). Qualitative content analysis is one of numerous research methods used to analyze text data. Research using qualitative content analysis focuses on the characteristics of language as communication with attention to the content or contextual meaning of the text (Budd, Thorp, \& Donohew, 1967). Text data in verbal, print, or electronic form and have been obtained from narrative responses, open-ended survey questions, interviews, focus groups, observations, or print media such as articles, books, or manuals (Kondracki \& Wellman, 2002). The goal of content analysis is "to provide knowledge and understanding of the phenomenon under study" (Downe-Wamboldt, 1992). Present study followed the content analysis to analysisthe messages delivered retailers in Mannar District.

Coding is an analytical process in which data, in both quantitative form results or qualitative is categorized to facilitate analysis. Coding means the transformation of data into a form understandable manner. All the data analysis procedures were accomplished with assistance of coding in this research. According to 
Malhotra \& Dash (2013) Coding means the assigning a code, usually a number, to each possible response to. Coding is intended as a reference to supplement those existing works. This manual focuses exclusively on codes and coding and how they play a role in the qualitative data analytic process.

Table 1: Classification, of Promotional messages on product type and message category.

\begin{tabular}{|c|c|c|c|}
\hline No & Promotional message & Product type & Message category \\
\hline 1. & $\begin{array}{l}\text { Soft and smoothness } \\
\text { Full day moisturizing. } \\
\text { Shower soft experience } \\
\text { Seven fragrance }\end{array}$ & Soap & Product oriented \\
\hline 2. & $\begin{array}{l}\text { Gentle baby care } \\
\text { Safe on skin } \\
\text { Proteins content }\end{array}$ & Soap & Product oriented \\
\hline 3. & $\begin{array}{l}\text { New engine and tubeless tire with high } \\
\text { warranty }\end{array}$ & Pleasure bike & Product oriented \\
\hline 4. & $\begin{array}{l}\text { Full capacity engine, high level } \\
\text { warranty and velocity }\end{array}$ & Maxi truck (jeeto) & Product oriented \\
\hline 5. & Significant travel and unique & Motor bike (Yamaha) & Product oriented \\
\hline 6. & Innovation and enjoy & Motor plus & Process oriented \\
\hline 7. & Gift offer & Motor product & Product oriented \\
\hline 8. & Control the pest and new grade & Pesticides (peld) & Product oriented \\
\hline 9. & New changes and control the pest & Pesticides (kiseki) & Product oriented \\
\hline 10. & Environment protection & Pesticides (evisecd) & $\begin{array}{l}\text { Environ mental } \\
\text { reality }\end{array}$ \\
\hline 11. & Protect the paddy and control the pest & Pesticides (nomini) & Product oriented \\
\hline 12. & Spraying skill and more benefits & $\begin{array}{l}\text { Pesticides (break } \\
\text { Throo) }\end{array}$ & Product oriented \\
\hline 13. & Pest control and quick response & $\begin{array}{l}\text { Herbicides } \\
\text { (sedpridilaclor) }\end{array}$ & Product oriented \\
\hline 14. & International quality packing & Herbicides (tayisdar) & Process oriented \\
\hline 15. & $\begin{array}{l}\text { Help to higher harvesting in paddy field } \\
\text { And win the trust of farmers. }\end{array}$ & $\begin{array}{l}\text { Nudec } \\
\text { Super-k(enriched) }\end{array}$ & Image oriented \\
\hline 16. & Bright future and high quality & $\begin{array}{l}\text { Education } \\
\text { (professional } \\
\text { Courses) }\end{array}$ & Process oriented \\
\hline 17. & $\begin{array}{l}\text { National diploma and graduation } \\
\text { in lower age }\end{array}$ & $\begin{array}{l}\text { Education (BTEC } \\
\text { National diploma in } \\
\text { Engineering) }\end{array}$ & Image oriented \\
\hline 18. & $\begin{array}{l}\text { Comprehensive coverage and } \\
\text { latest teaching }\end{array}$ & $\begin{array}{l}\text { Education } \\
\text { ( VLT CAMPUS) }\end{array}$ & Image oriented \\
\hline 19. & $\begin{array}{l}\text { High quality and higher } \\
\text { national diploma }\end{array}$ & $\begin{array}{l}\text { Education } \\
\text { (DEAKIN } \\
\text { UNIVERSITY) }\end{array}$ & Image oriented \\
\hline 20. & Affordable and internship & $\begin{array}{l}\text { Education } \\
\text { (be a doctor m.b.b.s) }\end{array}$ & Image oriented \\
\hline 21. & $\begin{array}{l}\text { Enterprise pillar and performance pillar } \\
\text { and financial pillar }\end{array}$ & $\begin{array}{l}\text { Cima } \\
\text { management level } \\
(\text { mcs })\end{array}$ & Image oriented \\
\hline 22. & $\begin{array}{l}\text { High efficient and lower electronic } \\
\text { consumption }\end{array}$ & $\begin{array}{l}\text { (Fan)electronic } \\
\text { Instruments }\end{array}$ & Product oriented \\
\hline 23. & High energy saving and high warranty & Electronic & Image oriented \\
\hline
\end{tabular}




\begin{tabular}{|c|c|c|c|}
\hline & & $\begin{array}{l}\text { Instruments } \\
\text { (singer refrigerator) }\end{array}$ & \\
\hline 24. & Bluetooth and based blasted & LG bower & Image oriented \\
\hline 25. & High power saving & Inverter & Image oriented \\
\hline 26. & $\begin{array}{l}\text { Unexpected consumption } \\
\text { and limit children behavior }\end{array}$ & Tablet & Product oriented \\
\hline 27. & Lower electronic consumption & Electric water pump & Product oriented \\
\hline 28. & Easy to work & Mixi(bullet den- b) & Product oriented \\
\hline 29. & More channels and enjoy the world & Dialog TV & Image oriented \\
\hline 30. & $\begin{array}{l}\text { Digital interest and free service, } \\
\text { lower interest }\end{array}$ & Seylfie account & Product oriented \\
\hline 31. & Scholarship offers and high value prizes & Runkekulu (BOC) & Image oriented \\
\hline 32. & $\begin{array}{l}\text { Varthana salary booster account and } \\
\text { Great life with saving }\end{array}$ & Deposit(DFCC bank) & Image oriented \\
\hline 33. & Enjoy with music & Getset(Goyo) & Product oriented \\
\hline 34. & $\begin{array}{l}\text { Fastest network and more data } \\
\text { affordable }\end{array}$ & Internet card & Process oriented \\
\hline 35. & $\begin{array}{l}\text { Bill payment and easy to work } \\
\text { Transfer facility and insurance payment }\end{array}$ & Ez cash & Process oriented \\
\hline 36. & Montero offer and more opportunity & Cash bonanza & Process oriented \\
\hline 37. & Grooviest tune and best collection & M tunes & Product oriented \\
\hline 38. & $\begin{array}{l}\text { Valued package and free minute } \\
\text { and data grams }\end{array}$ & Post- paid & Process oriented \\
\hline 39. & Full body massages and meditation & $\begin{array}{c}\text { Service of } \\
\text { Ayurvedic Center }\end{array}$ & Process oriented \\
\hline 40. & $\begin{array}{l}\text { Environment protection and } \\
\text { high quality material and compound paint }\end{array}$ & Wall kote paint & Integrated \\
\hline 41. & $\begin{array}{l}\text { Long term use and soundless, } \\
\text { easy to use and high quality }\end{array}$ & ASA polimar roof & Product oriented \\
\hline 42. & $\begin{array}{l}\text { Multi colors and long term use } \\
\text { New shape and design and confident }\end{array}$ & Chairs & Product oriented \\
\hline 43. & $\begin{array}{l}\text { Perfect portable and } \\
\text { Durable, high mobility and multiuse }\end{array}$ & Table mate & Product oriented \\
\hline 44. & High quality & Engine oil & Product oriented \\
\hline 45. & $\begin{array}{l}\text { Long term use and free gas slender, } \\
\text { Consolation prizes }\end{array}$ & Gas & Process oriented \\
\hline 46. & More confident, durable and attractive & Memorandum & Product oriented \\
\hline 47. & $\begin{array}{l}\text { Cotton and cool and extra cooling } \\
\text { And fitness, smooth and soft }\end{array}$ & Diapers & Product oriented \\
\hline 48. & Bright future and high salary & KFC employees & Process oriented \\
\hline 49. & Easy to use and soft and cool & Natural oil & Product oriented \\
\hline 50. & $\begin{array}{l}\text { Easy to select the three suitable outside } \\
\text { color for roof. }\end{array}$ & $\begin{array}{l}\text { Water tanks } \\
\text { (hybrid) }\end{array}$ & Product oriented \\
\hline
\end{tabular}

Carlson et al (1993) classified promotional message advertisements into five types as 1) Product oriented messages are oriented towards to product's specifications 2) process oriented advertising messages are oriented towards firms' process 3) Image oriented -claims make the company related with common activity or effect which is supported by public 4) environmental reality: promotional messages related to environmental real problems 5) integrated: any one messages consisted of product, product, image. environmental reality explained as an integrated message. Table 1 explains the message types, those are categorized into product oriented promotional messages, process oriented promotional messages, image 
oriented promotional messages, environmental reality messages and integrated promotional messages. Product oriented promotional messages are great number compared to other categories. Environmental reality, and Integrated promotional messages are very few compared to other messages. Form the table 1 it could be seen that no environmental reality advertisements were found from the contents of the promotional messages conveyed by the retailers in Mannar.

Table 2: Classification based on message contents

\begin{tabular}{|c|c|c|}
\hline No & Product type & Content. \\
\hline 1. & Soap (velvet) & $\begin{array}{ll}\text { - } & \text { Soft experience } \\
\text { - } & \text { Seven attractive } \\
\text { - } & \text { Fragrance daily } \\
\text { - } & \text { Keeping skin in cool } \\
\end{array}$ \\
\hline 2. & Soap(baby) & $\begin{array}{ll}\text { - } & 100 \mathrm{~g} \text { new and big soap. } \\
\text { - } & \text { Price is } 50 /-, \text { pure and gentle baby soap } \\
\text { - } & \text { Olive oil and milk proteins. } \\
\text { - } & \text { Gentle care safe on skin. }\end{array}$ \\
\hline 3. & Pleasure bike & $\begin{array}{ll} & \text { New engine } \\
- & \text { Tubeless tire } \\
- & \text { High warranty } \\
\end{array}$ \\
\hline 4. & Maxi truck (jeeto) & $\begin{array}{ll}\text { - } & \text { Full capacity engine } \\
\text { - } & \text { High level warranty } \\
\text { - } & \text { High velocity }\end{array}$ \\
\hline 5. & Motor bike & $\begin{array}{ll}- & \text { Significant travel } \\
\text { - } & \text { Unique }\end{array}$ \\
\hline 6. & Motor plus & $\begin{array}{ll}- & \text { Innovation } \\
\text { - } & \text { Enjoy } \\
\end{array}$ \\
\hline 7. & Motor product & - Gift offer \\
\hline 8. & Pesticides (peld) & $\begin{array}{ll}\text { - } & \text { Control the pest } \\
\text { - } & \text { New grade }\end{array}$ \\
\hline 9. & Pesticides (kiseki) & $\begin{array}{ll}\text { - } & \text { New changes } \\
\text { - } & \text { Control the pest }\end{array}$ \\
\hline 10. & Pesticides (evisecd) & $\begin{array}{ll}\text { - } & \text { Environment protection } \\
\text { - } & \text { Control the pest }\end{array}$ \\
\hline 11. & Pesticides (nomini) & $\begin{array}{ll}\text { - } & \text { Protect the paddy } \\
\text { - } & \text { Control the pest }\end{array}$ \\
\hline 12. & Pesticides(break throo) & $\begin{array}{ll}- & \text { Spraying skill } \\
- & \text { More benefits } \\
\end{array}$ \\
\hline 13. & $\begin{array}{l}\text { Herbicides } \\
\text { (sedpridilaclor) }\end{array}$ & $\begin{array}{ll}\text { - } & \text { Pest control } \\
\text { - } & \text { Quick response }\end{array}$ \\
\hline 14. & Herbicides (tayisdar) & - $\quad$ International quality packing \\
\hline 15. & $\begin{array}{l}\text { Nudec } \\
\text { super-k(enriched) }\end{array}$ & $\begin{array}{l}\text { - Help to higher harvesting in paddy field } \\
\text { - } \quad \text { Win the trust of farmers. }\end{array}$ \\
\hline 16. & $\begin{array}{l}\text { Education } \\
\text { (professional courses) }\end{array}$ & $\begin{array}{ll}- & \text { Bright future } \\
- & \text { High quality }\end{array}$ \\
\hline 17. & $\begin{array}{l}\text { Education (BTEC } \\
\text { National diploma in } \\
\text { Engineering) }\end{array}$ & $\begin{array}{ll}\text { - } & \text { National diploma } \\
\text { - } & \text { Graduation } \\
\text { - } & \text { In lower age }\end{array}$ \\
\hline 18. & $\begin{array}{l}\text { Education } \\
\text { ( VLT CAMPUS) }\end{array}$ & $\begin{array}{ll}\text { - } & \text { Comprehensive coverage } \\
\text { - } & \text { Latest teaching }\end{array}$ \\
\hline
\end{tabular}




\begin{tabular}{|c|c|c|}
\hline 19. & $\begin{array}{l}\text { (DEAKIN } \\
\text { UNIVERSITY) }\end{array}$ & $\begin{array}{ll}\text { - } & \text { High quality } \\
\text { - } & \text { Higher national diploma Education }\end{array}$ \\
\hline 20. & $\begin{array}{l}\text { Education } \\
\text { (Be a doctor M.B.B.S) }\end{array}$ & $\begin{array}{ll}\text { - } & \text { Affordable } \\
\text { - } & \text { Internship }\end{array}$ \\
\hline 21. & $\begin{array}{l}\text { CIMA(MCS) } \\
\text { management level }\end{array}$ & $\begin{array}{ll}\text { - } & \text { Enterprise pillar } \\
\text { - } & \text { Performance pillar } \\
\text { - } & \text { Financial pillar } \\
\end{array}$ \\
\hline 22. & $\begin{array}{l}\text { (Fan)electronic } \\
\text { instruments }\end{array}$ & $\begin{array}{ll}\text { - } & \text { High efficient } \\
\text { - } & \text { Lower electronic } \\
\text { - } & \text { Consumption } \\
\end{array}$ \\
\hline 23. & $\begin{array}{l}\text { electronic } \\
\text { instruments (singer refrigerator) }\end{array}$ & $\begin{array}{ll}- & \text { High energy saving } \\
\text { - } & \text { High warranty }\end{array}$ \\
\hline 24. & LG bower & $\begin{array}{ll}\text { - } & \text { Bluetooth } \\
\text { - } & \text { Based blasted }\end{array}$ \\
\hline 25. & Inverter & - $\quad$ High power saving \\
\hline 26. & Tablet & $\begin{array}{ll} & \text { Unexpected consumption } \\
\text { - } & \text { Limit children behavior } \\
\end{array}$ \\
\hline 27. & Electric water pump & - Lower electronic consumption \\
\hline 28. & Mixi(bullet den- b) & - $\quad$ Easy to work \\
\hline 29. & Dialog TV & $\begin{array}{ll}- & \text { More channels } \\
\text { - } & \text { Enjoy the world }\end{array}$ \\
\hline 30. & Seylfie account & $\begin{array}{ll}\text { - } & \text { Digital interest } \\
\text { - } & \text { Free service } \\
\text { - } & \text { Lower interest }\end{array}$ \\
\hline 31. & Runkekulu (BOC) & $\begin{array}{ll}\text { - } & \text { Scholarship offers } \\
\text { - } & \text { High Value Prizes } \\
\end{array}$ \\
\hline 32. & Deposit(DFCC bank) & $\begin{array}{ll}\text { - } & \text { Varthana salary booster account } \\
\text { - } & \text { Great life with saving }\end{array}$ \\
\hline 33. & Getset(goyo) & - $\quad$ Enjoy with music \\
\hline 34. & Internet card & $\begin{array}{ll}- & \text { Fastest net work } \\
\text { - } & \text { More data } \\
\text { - } & \text { Affordable } \\
\end{array}$ \\
\hline 35. & Ez cash & $\begin{array}{ll}\text { - } & \text { Bill payment } \\
\text { - } & \text { Easy to work } \\
\text { - } & \text { Transfer facility } \\
\text { - } & \text { Insurance payment } \\
\end{array}$ \\
\hline 36. & Cash bonanza & $\begin{array}{ll}- & \text { Montero offer } \\
\text { - } & \text { More opportunity } \\
\end{array}$ \\
\hline 37. & M tunes & $\begin{array}{ll}- & \text { Grooviest tune } \\
\text { - } & \text { Best collection } \\
\end{array}$ \\
\hline 38. & Post- paid & $\begin{array}{ll}\text { - } & \text { Valued package } \\
\text { - } & \text { Free minute } \\
\text { - } & \text { Data grams } \\
\end{array}$ \\
\hline 39. & $\begin{array}{l}\text { Service of ayulvedic } \\
\text { Center }\end{array}$ & $\begin{array}{ll}\text { - } & \text { Full body massages } \\
\text { - } & \text { Meditation } \\
\end{array}$ \\
\hline 40. & Wall kote paint & $\begin{array}{ll}- & \text { Environment protection } \\
\text { - } & \text { High quality material } \\
\text { - } & \text { Compound paint } \\
\end{array}$ \\
\hline
\end{tabular}




\begin{tabular}{|c|c|c|}
\hline 41. & ASA polimar roof & $\begin{array}{ll}- & \text { Long term use } \\
\text { - } & \text { Soundless } \\
\text { - } & \text { Easy to use } \\
\text { - } & \text { High quality }\end{array}$ \\
\hline 42. & Chairs & $\begin{array}{ll}\text { - } & \text { Multi colors } \\
\text { - } & \text { Long term use } \\
\text { - } & \text { 43new shape and design and confident }\end{array}$ \\
\hline 43. & Table mate & $\begin{array}{ll}\text { - } & \text { Perfect portable } \\
\text { - } & \text { Durable } \\
\text { - } & \text { High mobility } \\
\text { - } & \text { Multiuse }\end{array}$ \\
\hline 44. & Engine oil & - $\quad$ High quality \\
\hline 45. & Gas & $\begin{array}{ll} & \text { Long term use } \\
\text { - } & \text { Free gas slender, } \\
\text { - } & \text { Consolation prizes } \\
\end{array}$ \\
\hline 46. & Memorandum & $\begin{array}{ll}\text { - } & \text { More confident } \\
\text { - } & \text { Durable } \\
\text { - } & \text { Attractive }\end{array}$ \\
\hline 47. & Diapers & $\begin{array}{ll}\text { - } & \text { Cotton and cool } \\
\text { - } & \text { Extra cooling } \\
\text { - } & \text { Fitness } \\
\text { - } & \text { Smooth and soft } \\
\end{array}$ \\
\hline 48. & KFC employees & $\begin{array}{ll} & \text { Bright future } \\
\text { - } & \text { High salary } \\
\end{array}$ \\
\hline $\begin{array}{r}49 . \\
-89 \\
\end{array}$ & Natural oil & $\begin{array}{ll}- & \text { Easy to use } \\
- & \text { Soft and cool } \\
\end{array}$ \\
\hline 50 & $\begin{array}{l}\text { Water tanks } \\
\text { (hybrid) }\end{array}$ & $\begin{array}{l}\text { - } \quad \text { Easy to select the three suitable outside } \\
\text { - } \quad \text { Color for roof. }\end{array}$ \\
\hline
\end{tabular}

\section{Conclusion}

After conflict resolution many retailers were entered in to Mannar, to capture their new geographical segment. Having good messages as strategic benefit for the retailers to compete in the market, because those message are medium for communication, which are designed to be delivered to capture customers in a market. Present study selected 50 promotional messages. These promotional messages contained 24 newspaper advertisement and 26 catalogs. Most of the promotional advertisements contented of pesticide advertisements which target framers in the market. Based on Carlson's classification contents are summarized based on product oriented, process oriented, image oriented, environmental reality, and integrated messages.

There are 26 product oriented promotional messages, 10 process oriented promotional messages, 12 image oriented Promotional messages, 1 environmental reality promotional message, and 1 integrated promotional messages were identified in this research. Environmental reality and integrated messages are insufficient in the contents identified in this study. The consumers expectantly respond to environmental reality advertising, the companies and their products, the firms should stress their environmental reality actions, which will allow consumers to differentiate between "environment reality" firms and "non-environment reality" firms. In addition, the application of environment reality methods in production and green product attributes should be emphasized to convince and attract consumers. A green advertising campaign should be associated with a clear, transparent, understandable and concise environmental claim, through which the 
firms will be able to grab the consumers' attention (Bing Zhu ,2013). Therefore, retailers can change their promotional messages to green perspectives.

The chosen promotional messages conveyed by the retailers were not represented the whole population. Similarly, the sample was primarily taken from the advertisements and catalogs, designed by the Mannar Retailers, and consequently it was not geographically representative. This research merely analyzed the promotional messages based on the Carlson (1993) classification.

Based on the findings and the conclusions discussed above, various suggestions for future researchers can be offered. These suggestions such as from this research study it was clear that the sample consists of small amount, an area that would benefit from more detailed investigation, although this study consisted of 50 sample form a given time frame, time can be extended and more advertisements messages will be analyzed further to have different category of messages. Future research can explore the response of the consumers towards the promotional messages conveyed by the retailers.

\section{References}

Alexander, M. W., \& Judd, B. (1978). Do nudes in ads enhance brand recall. Journal of Advertising Research, 18(1), 47-50.

Amirani, S., \& Gates, R. (1993). An attribute-anchored conjoint approach to measuring store image. International Journal of Retail \& Distribution Management, 21(5).

Achchuthan Sivapalan, Charles Jebarajakirthy, (2017) "An application of retailing service quality practices influencing customer loyalty toward retailers", Marketing Intelligence \& Planning, Vol. 35 Issue: 7, pp.842-857, https://doi.org/10.1108/MIP-09-2016-0178

Beaudoin, P., Moore, M. A., \& Goldsmith, R. E. (1998). Young fashion leaders' and followers' attitudes toward American and imported apparel. Journal of Product \& Brand Management, 7(3), 193-207.

Belch, G. E., \& Belch, M. A. (2003). Advertising and promotion: An integrated marketing communications perspective. The McGraw- Hill.

Bovee, C. L., \& Arens, W. F. (1992). Contemporary Advertising. Richard D. Irwin.

Brown, A. D., \& Starkey, K. (1994). The effect of organizational culture on communication and information. Journal of Management studies, 31(6), 807-828.

Cholachatpinyo, A., Fletcher, B., Padgett, I., \& Crocker, M. (2002). A conceptual model of the fashion process-part 1: the fashion transformation process model. Journal of Fashion Marketing and Management: An International Journal, 6(1), 11-23.

Cristina Ziliani, Marco Ieva, (2015) "Retail shopper marketing: the future of promotional flyers", International Journal of Retail \& Distribution Management, Vol. 43 Issue: 6, pp.488502, https://doi.org/10.1108/IJRDM-02-2014-0022

Creswell, J. W., Hanson, W. E., Clark Plano, V. L., \& Morales, A. (2007). Qualitative research designs: Selection and implementation. The counseling psychologist, 35(2), 236-264.

Davies, G., \& Brooks, J. (1989). Positioning strategy in retailing. Chapman.

Dellarocas, C., \& Narayan, R. (2006, December). What motivates consumers to review a product online? A study of the product-specific antecedents of online movie reviews. In WISE (pp. 1-6).

Driessen, C. E. (2005). Message communication in advertising: Selling the Abercrombie and Fitch image. Journal of Undergraduate Research, 8, 1-12.

Esbjerg, L., \& Bech-Larsen, T. (2009). The brand architecture of grocery retailers: setting material and symbolic boundaries for consumer choice. Journal of Retailing and Consumer Services, 16(5), 414423.

Fenech Adami, M., \& Kiger, A. (2005). The use of triangulation for completeness purposes: Nurse Researcher, 12(4), 19-29.

Fernández-Martínez, R., Loredo, J., Ordóñez, A., \& Rucandio, M. I. (2006). Physicochemical characterization and mercury speciation of particle-size soil fractions from an abandoned mining area in Mieres, Asturias (Spain). Environmental Pollution, 142(2), 217-226. 
French, A., \& Smith, G. (2010). Measuring political brand equity: a consumer oriented approach. European Journal of Marketing, 44(3/4), 460-477.

Goh, J. Y., Tan, E. F., Tiyu, S. X., \& Lee, K. C. (2013). The relationship between brand perceptions and brand satisfaction on skin care products (Doctoral dissertation, UTAR).

Grazer, W. F., \& Keesling, G. (1995). The effect of print advertising's use of sexual themes on brand recall and purchase intention: A product specific investigation of male responses. Journal of Applied Business Research, 11(3), 47.

Gunn, M. (2011). The Potential for Retailers to Practice 'Choice Editing'As a Policy Tool for Sustainable Consumption (Doctoral dissertation, Lunds Universitet).

Gunn, M., \& Mont, O. (2014). Choice editing as a retailers' tool for sustainable consumption. International Journal of Retail \& Distribution Management, 42(6), 464-481.

Hunt, J., Breuker, C. J., Sadowski, J. A., \& Moore, A. J. (2009). Male-male competition, female mate choice and their interaction: determining total sexual selection. Journal of evolutionary biology, 22(1), 13-26.

Hutchinson, A. M., \& Johnston, L. (2004). Bridging the divide: a survey of nurses' opinions regarding barriers to, and facilitators of, research utilization in the practice setting. Journal of clinical nursing, 13(3), 304-315.

Hyllegard, K., Ogle, J., \& Yan, R. N. (2009). The impact of advertising message strategy-fair labour v. sexual appeal-upon Gen Y consumers' intent to patronize an apparel retailer. Journal of Fashion Marketing and Management: An International Journal, 13(1), 109-127.

, Denise Ong, (2007) "An investigation of the effects of environmental claims in promotional messages for clothing brands", Marketing Intelligence \& Planning, Vol. $25 \quad$ Issue: $\quad 7, \quad$ pp.772788, https://doi.org/10.1108/02634500710834214

Jackson, T. (2005). Motivating sustainable consumption. Sustainable Development Research Network, 29 , 30.

Jin, B., Yu, H., \& Hye Kang, J. (2013). Challenges in Western-Chinese business relationships: The Chinese perspective. Marketing Intelligence \& Planning, 31(2), 179-192.

Johns, N., \& Pine, R. (2002). Consumer behaviour in the food service industry: a review. International Journal of Hospitality Management, 21(2), 119-134.

Jones, B., Bowd, R., \& Tench, R. (2009). Corporate irresponsibility and corporate social responsibility: competing realities. Social Responsibility Journal, 5(3), 300-310.

Kalra, A., \& Goodstein, R. C. (1998). The impact of advertising positioning strategies on consumer price sensitivity. Journal of Marketing Research, 210-224.

Kaul, A., \& Wittink, D. R. (1995). Empirical generalizations about the impact of advertising on price sensitivity and price. Marketing Science, 14(3_supplement), G151-G160.

Krause, C., Müller-Benedict, V., \& Wiesmann, U. (2000, June). Small Children--Big Data. Possible Links Between Qualitative and Quantitative Methods in the Analysis of Self-Reports. In Forum: Qualitative Social Research (Vol. 1, No. 2).

Langenberg, M., Frommer, J., \& Tress, W. (1993). A qualitative research approach to analytical music therapy. Music Therapy, 12(1), 59-84.

LaTour, M. S., \& Henthorne, T. L. (1994). Ethical judgments of sexual appeals in print advertising. Journal of advertising, 23(3), 81-90.

Markoff, J., Shapiro, G., \& Weitman, S. R. (1975). Toward the integration of content analysis and general methodology. Sociological methodology, 6, 1-58.

Maxwell, J. A. (2012). Qualitative research design: An interactive approach (Vol. 41). Sage publications.

Moore, L. W., \& Miller, M. (1999). Initiating research with doubly vulnerable populations. Journal of Advanced Nursing, 30(5), 1034-1040.

Michael Clayton, Jun Heo, (2011) "Effects of promotional-based advertising on brand associations", Journal of Product \& Brand Management, Vol. 20 Issue: 4, pp.309315, https://doi.org/10.1108/10610421111148324

Newman, A. J., \& Patel, D. (2004). The marketing directions of two fashion retailers. European Journal of Marketing, 38(7), 770-789. 
Newman, A., \& Cullen, P. (2002). Retailing: environment \& operations. Cengage Learning EMEA.

Patton, J. (2002, November). Hitting the target: adding interaction design to agile software development. In OOPSLA 2002 Practitioners Reports .ACM.

Peattie, K., \& Collins, A. (2009). Guest editorial: perspectives on sustainable consumption. International Journal of Consumer Studies, 33(2), 107-112.

Peattie, K., \& Ringer, A. (1994). Management and the environment in the UK and Germany: a comparison. European Management Journal, 12(2), 216-225.

Peattie, S. (1998). Promotional competitions as a marketing tool in food retailing. British Food Journal, 100(6), 286-294.

Phau, I., \& Ong, D. (2007). An investigation of the effects of environmental claims in promotional messages for clothing brands. Marketing Intelligence \& Planning, 25(7), 772-788.

Rohlik, E. (2015). Quality of Life Awareness and Effect on Critical Care Nursing Interventions With Persons with Tetraplegia (Doctoral dissertation, Walden University).

Schilling, J. (2006). On the pragmatics of qualitative assessment. European Journal of Psychological Assessment, 22(1), 28-37.

Schwarz, N. (2004). Metacognitive experiences in consumer judgment and decision making. Journal of Consumer Psychology, 14(4), 332-348.

Severn, J., Belch, G. E., \& Belch, M. A. (1990). The effects of sexual and non-sexual advertising appeals and information level on cognitive processing and communication effectiveness. Journal of advertising, 19(1), 14-22.

Speck, P. S., \& Elliott, M. T. (1997). Predictors of advertising avoidance in print and broadcast media. Journal of Advertising, 26(3), 61-76.

Sunday, A., \& Bayode, B. (2011). Strategic influence of promotional mix on organisation sale turnover in the face of strong competitors. Management \& Marketing-Craiova, (1), 67-76.

Tan, S. J., \& Hwang Chua, S. (2004). "While stocks last!" Impact of framing on consumers' perception of sales promotions. Journal of Consumer Marketing, 21(5), 343-355.

Treise, D., Weigold, M. F., Conna, J., \& Garrison, H. (1994). Ethics in advertising: Ideological correlates of consumer perceptions. Journal of Advertising, 23(3), 59-69.

Tsai, S. P. (2005). Integrated marketing as management of holistic consumer experience. Business Horizons, 48(5), 431-441.

Villarejo-Ramos, A. F., \& Sanchez-Franco, M. J. (2005). The impact of marketing communication and price promotion on brand equity. Journal of Brand Management, 12(6), 431-444.

Vimal, J., \& Subramani, R. (2017). Understanding Qualitative Content Analysis in the Light of Literary Studies. Language in India, 17(3).

Walters, D., \& Laffy, D. (1996). Managing retail productivity and profitability. Hampshire: Palgrave Macmillan.

White, M. D., \& Marsh, E. E. (2006). Content analysis: A flexible methodology. Library trends, 55(1), 2245.

Wiegand, H. E. (2015). Nachträge. Walter de Gruyter GmbH \& Co KG.

Williams, C. (2011). Research methods. Journal of Business \& Economics Research (JBER), 5(3).

Yang, M. L. (2005). Creating the kitchen patriot: Media promotion of food rationing and nutrition campaigns on the American home front during World War II. American Journalism, 22(3), 55-75.

Yoo, B., Donthu, N., \& Lee, S. (2000). An examination of selected marketing mix elements and brand equity. Journal of the academy of marketing science, 28(2), 195-211.

Ziliani, C., \& Ieva, M. (2015). Retail shopper marketing: the future of promotional flyers. International Journal of Retail \& Distribution Management, 43(6), 488-502. 